\title{
Medical Image
}

National Cancer Institute

\section{Source}

National Cancer Institute. Medical Image. NCI Thesaurus. Code C19477.

Any record of a medical imaging event whether physical or electronic. 